ECONOMICS

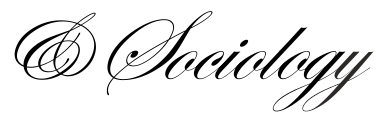

Sadraddin Eslami, Az̧man Hashim International Business School, Universiti Teknologi Malaysia, Johor, Malaysia

E-mail:eslami18@yahoo.com

\section{Zainab Khalifah,} Azman Hashim International Business School, Universiti

Teknologi Malaysia, Johor, Malaysia

E-mail:

zainab@management.utm.my
Abbas Mardani,
Azman Hashim International
Business School,
Universiti Teknologi Malaysia,
Johor, Malaysia
E-mail: mabbas3@live.utm.my

Dalia Streimikiene, Lithuanian Institute of Agrarian Economics,

Vilnius, Lithuania

E-mail:dalia@mail.lei.lt

Received: April, 2018

1st Revision: July, 2018

Accepted: November, 2018

DOI: $10.14254 / 2071-$

789X.2018/11-4/12

JEL Classification: Z3
Eslami, S., Khalifah, Z., Mardani, A., \& Streimikiene, D. (2018). Impact of noneconomic factors on residents' support for sustainable tourism development in Langkawi Island, Malaysia. Economics and Sociology, 11(4), 181-197. doi:10.14254/2071-789X.2018/11-4/12

\section{IMPACT OF NON-ECONOMIC FACTORS ON RESIDENTS' SUPPORT FOR SUSTAINABLE TOURISM DEVELOPMENT IN LANGKAWI ISLAND, MALAYSIA}

\begin{abstract}
This study offers a structural model based on the social exchange theory (SET) and bottom-up spillover theory. The model presents a discussion on the relationships among non-economic factors including perceived sociocultural and environmental impacts of tourism, satisfaction with the way of life and recreation amenities domains, overall quality of life satisfaction and residents support for sustainable tourism development (SSTD) This study uses self-administered survey and employs structural equation modeling (SEM) approach, using the sample of 542 local residents in six different districts of Langkawi Island, Malaysia. The findings reveal that perceived environmental impacts of tourism as a non-economic factor did not influence the domain of residents' way of life, while it had a significant impact on the domain of recreation amenities. Moreover, perceived sociocultural impacts of tourism influenced both residents' satisfaction with the way of life and recreation amenities life domains, which in turn affected overall quality of life satisfaction. Finally, overall quality of life satisfaction significantly influenced the residents' ultimate SSTD. Theoretical contributions of this research along with practical implications are also discussed.
\end{abstract}

Keywords: sustainable tourism, structural equation modeling, quality of life, bottom-up spillover theory, social exchange theory, non-economic factors, Langkawi. 


\section{Introduction}

Sustainable tourism (ST) is a major focus in the debate on environmentally integrated tourism development and it is a form of tourism which is based on the principles of sustainable development, (UNEP/WTO, 2005; Butler, 1999; Mowforth \& Munt, 2003; Nunkoo \& Ramkissoon, 2011b; Strielkowski, 2017). The World Tourism Organization (WTO, 1998, p. 21) defines sustainable tourism development as meeting the needs of present tourists and host regions while protecting and enhancing opportunities for the future. It is envisaged as leading to the management of all resources in such a way that economic, social and aesthetic needs can be fulfilled while maintaining cultural integrity, essential ecological processes, biological diversity, and life support systems.

Since in developing countries, tourism industry is often one of the most effective and significant economic elements as compared to the other traditional sectors (Kibicho, 2004; Chen, Wang \& Xu, 2017), itis considered to be a resource-intensive industry for which varied categories of resources are utilized, thus it needs to be accountable in terms of sustainability at both local and global scales (Kot, 2018; Pjerotic, 2017). A community that plans and uses tourism as an alternative means of strengthening its economic development must develop sustainable tourism to meet the needs and demands of its residents (Puczko \& Ratz, 2000; Lee, 2013). However, such a development is difficult without participation and support of the community residents and there is little clarity as to how best to resolve this problem (Fallon \& Kriwoken, 2003; Waligo \& Hawkins, 2013; Nicholas, Thapa, \& Ko, 2009; Huong \& Lee, 2017).

Studies report that for a destination to have a successful tourism industry; it needs to meet or even surpass the expectations of visitors and should further be perceived as creating more benefits to local residents than costs (Ap, 1992; Gursoy \& Rutherford, 2004; Ribeiro, Valle, \& Silva, 2013; Strielkowski, 2018). These factors (costs/benefits of tourism) and several other factors (Androniceanu, 2017; Niemczyk, 2015) such as community involvement (Lee, 2013), residents' place image (Stylidis et al., 2014), economic dependence (Chen and Chen, 2010), place identity (Chen, Wang \& Xu, 2017) substantially influence residents' support for tourism development (Perdue, Long, \& Allen, 1990; Nunkoo \& Ramkissoon, 2011a; Egresi \& Kara, 2016; Luekveerawattana, 2018). Accordingly, understanding and examining various related anticipants of residents' support for sustainable tourism development (SSTD) can help to promote it because communities can assess these precedents to predict the level of support by their residents (Tovar \& Lockwood, 2008; Vargas-Sanchez, Plaza-Mejia, \& Porras-Bueno, 2009; Huong \& Lee, 2017).

Literature shows that factors which influence local community's support for tourism development have been studied quite broadly (Northcote \& Macbeth, 2005; Chen \& Chen, 2010; Hanafiah, Jamaluddin, \& Zulkifly, 2013; Huong \& Lee, 2017). Nonetheless, to date no studies have theoretically integrated a conceptual model to empirically study and discuss the relationship between the residents' perceptions of non-economic factors alone and their support for sustainable tourism development (SSTD) in the context of island environment.

Researchers state that while utilitarian economics disregards tourism effects of noneconomic benefits, social exchange theory (SET) advises that in a tourist destination, residents not only consider economic benefits but also, they reflect on non-economic benefits and factors of tourism presence in their community (Jun, Pongsata \& Noh, 2016). As a result, understanding what kind of the perceptions residents have about the impacts of tourism and their level of support for its development, is considered vital for the planning of sustainable tourism development (Ritchie \& Inkari, 2006; Gursoy, Chi, \& Dyer, 2010; Stylidis \& Terzidou, 2014; Huong \& Lee, 2017). 
Therefore, building on the previous modelling attempts, based on the social exchange theory and bottom up spill-over theory; the purpose of this study is to develop the existing tourism support models by examining the residents' perceptions of non-economic factors (perceived environmental, sociocultural impacts of tourism, satisfaction with non-material life domains and overall quality of life) towards SSTD in the case of Langkawi Island, Malaysia.

\section{Theoretical background and hypotheses development}

The following section describes the theories and constructs applied in the proposed model of study and the hypothesized relationships (see Fig. 1).

According to literature, SET is a dominated framework in evaluating residents' perceptions regarding support for tourism (Nunkoo \& Ramkissoon, 2012; Nunkoo \& So, 2016; Strzeleckaet al., 2017). The theory proposes that, those residents who perceive more benefits of tourism development in their community as compared with its costs, tend to support tourism and get involved more in an exchange interaction to gain value of it (Ko \& Stewart, 2002; Gursoy, Chi, \& Dyer, 2009; Nunkoo \& Ramkissoon, 2011b). Wang and Pfister (2008) argue that benefits can be considered as value, and they further note that in an exchange process, economic as well as non-economic value domains are important and may influence an attitude to tourism. Such a view is also shared by Homans (1961) who argues that exchange theory is based on the premise that social interaction is based not only on exchange of activity on tangible but also on intangibles, reinforcing the need for researchers to consider the non-economic value domains in the interaction process. Although studies that have adopted SET to explain the relationship between benefits derived from the industry and support for tourism remain popular in the literature (Andereck et al., 2005; Jurowski, Uysal, \& Williams, 1997; McGehee \& Andereck, 2004; Strzelecka et al., 2017), they appear to provide an understanding more on the economic value areas with a neglect of the immaterial ones.

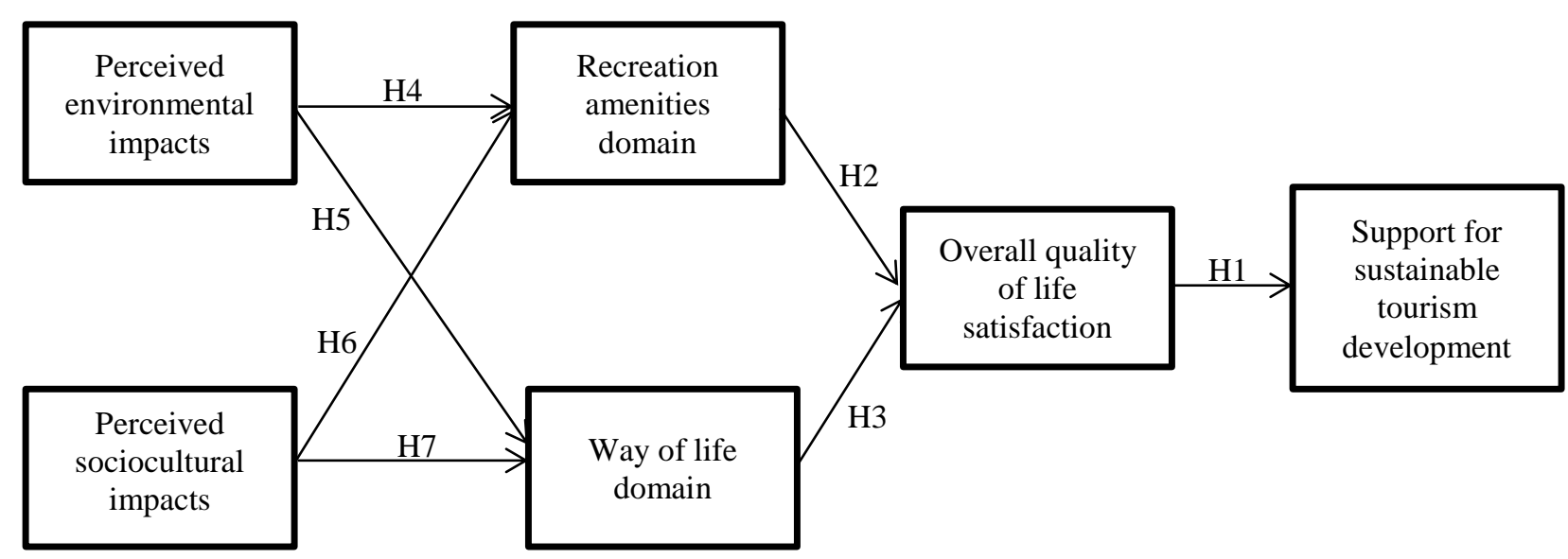

Figure 1. Proposed conceptual framework of residents' support for sustainable tourism development

The other fundamental theory applied in this study is bottom-up spillover theory to support and elaborate quality of life construct under which various life domains and subdomains (i.e. economic, non-economic, etc.) are categorized (Woo, Kim, \& Uysal, 2015). In an attempt to contribute to the literature, researchers have discussed the importance of quality of life satisfaction towards support for tourism development, recommending that there is a connection between residents' quality of life and their support for tourism development; 
however, few studies have examined the residents' perceptions regarding impacts which tourism has on their quality of life and their ultimate support towards tourism development in their community (Andereck \& Nyaupane, 2011; Yu, Chancellor, \& Cole, 2011). The model of current study (Figure 1) applies two non-economic life domains which are the two important domains of overall quality of life including recreation amenities and way of life. These two life domains and the related subdomains positively or negatively affect people's overall quality of life. Additionally, the two non-economic factors of tourism impacts include sociocultural and environmental impacts towards SSTD.

\subsection{Endogenous and ultimate dependent variables}

Residents' SSTD is examined as the ultimate dependent variable of the study. The model also proposes quality of life satisfaction construct along with two of its life domains as the mediating variable between the exogenous latent variables perceived sociocultural and environmental impacts of tourism and the ultimate dependent variable.

Previous studies show that the concept of quality of life can be described by the bottom-up spill over theory (Sirgy \& Lee, 2006; Woo, Kim, \& Uysal, 2014; Woo, Kim, \& Uysal, 2015). The theory indicates that "the effect within a life domain spills over vertically to the most superordinate domain (life in general), thus identifying overall life satisfaction". These subdomains and life domains consist of various factors such as health, safety, family, social, recreation, way of life, arts and culture, work, recreation, financial, spiritual, intellectual, travel, and social life (Uysal, Perdue, \& Sirgy, 2012; Andereck \& Nyaupane, 2011; Shuaibu \& Oladayo, 2016). Accordingly, the greater the satisfaction with recreation amenities and way of life, the greater the satisfaction with life in general will be (Neal, Sirgy, \& Uysal, 1999).

Furthermore, studies recommend that residents' satisfaction with quality of life influences their support for tourism development (Woo, Kim, \& Uysal, 2015; Mihalicet al., 2016). If tourism brings about a lower quality of life, residents may be reluctant to support further tourism development in their community (Woo, Kim, \& Uysal, 2015). However, literature review shows that, most of previous studies have measured tourism impacts on the residents' satisfaction with quality of life as the final dependent variable (Perdue, Long, \& Kang, 1999; Andereck \& Vogt, 2000; Kim, Uysal, \& Sirgy, 2013). Whilst, tourism researchers suggested that research should further test residents' satisfaction with quality of life in relation with support for tourism, as few research has been done in this respect with inadequate empirically tested outcome (Croes, 2012; Uysal, Perdue, \& Sirgy, 2012; Woo, Kim, \& Uysal, 2015). Such a gap is more serious when it goes to the relationship between residents' quality of life satisfaction with the inclusion of non-economic life domains and particularly SSTD which is a newly emerged concept of tourism development. Hence, the current study tests this relationship; and the following hypotheses are suggested:

H1. Overall quality of life satisfaction positively influences residents' SSTD.

H2. There is a positive relationship between recreation amenities well-being domain and overall quality of life satisfaction.

H3. There is a positive relationship between way of life well-being domain and overall quality of life satisfaction.

\subsection{Exogenous latent variables}

Two non-economic factors of tourism impacts (sociocultural and environmental impacts of tourism) are evaluated on two non-material life domains (way of life and recreation amenities) which are the two important life domains of overall life satisfaction. 
Research shows that residents pay much attention to recreation amenities and entertainment including participation in the festivals, fairs, museum, and watching live sports, and expect that when tourism is developed in their community, it improves such opportunities. Residents further consider way of life as an important factor since it is about their traditional or rural lifestyle and personal manner of living which they want to have it preserved from negative changes due to impacts of tourism development in their community (Andereck \& Nyaupane, 2011; Streimikiene \& Bilan, 2015). Studies further stated that individuals view tourism as an advantage which increases recreational opportunities in their community (Yu, Chancellor, \& Cole, 2011). However, environmental and social costs of tourism including overused recreational resources by tourists, traffic congestion, overcrowdedness, and crimes negatively influence different life domains (e.g. residents' way of life and recreation amenities), resulting in overall life dissatisfaction (Anderecket al., 2007; Zhang, Cole, \& Chancellor, 2013).

Andereck and Nyaupane (2011) state that tourism is involved in cultural attractions, family structure, social networks, cultural integrity, and the festivals conducted as tourism activities and recreations. In another study, Kim (2002) indicated that due to positive impacts of tourism (improvement of local services, variety of entertainment); recreation amenities have improved in the community.

Overall, researchers emphasize that residents' particular life domains are influenced by their perceived positive and negative impacts of tourism including sociocultural and environmental impacts (Nawijn \& Mitas, 2012; Woo, Kim, \& Uysal, 2015; Mihalic et al., 2016); leading to individuals' satisfaction/dissatisfaction with overall quality of life (Aref, 2011; Jeon, Kang, \& Desmarais, 2014; Suntikul et al., 2016). Therefore, extending the logic of above discussions to the context of current study, the following hypotheses are proposed:

H4: A direct positive relationship exists between the perceived environmental impacts of tourism and satisfaction with recreation amenities well-being domain.

H5: A direct positive relationship exists between the perceived environmental impacts of tourism and satisfaction with way of life domain.

H6: A direct positive relationship exists between the perceived sociocultural impacts of tourism and satisfaction with recreation amenities well-being domain.

H7: A direct positive relationship exists between the perceived sociocultural impacts of tourism and satisfaction with way of life domain.

\section{Methodology}

\subsection{The study area}

The area chosen for this study is Langkawi Island which is situated in northwest part of Malaysia. The island has various natural tourist attractions such as flora and fauna, several beaches and a tropical climate, all of which have proven to be a good reason for the tourists to visit the place (Kayat, 2002). The total land area of Langkawi Island is 47848 ha, two-thirds of which are hilly areas. The island is located in the state of Kedah between latitude $6^{\circ} 10=\mathrm{N}$ $6^{\circ} 30=\mathrm{N}$ and longitude $99^{\circ} 35=\mathrm{E}-100^{\circ} \mathrm{E}$ with a distance around $51 \mathrm{~km}$ away from the mainland, and it is the largest of an archipelago of 104 islands in the Andaman Sea. There are six districts in Langkawi Island including Kuah, Padang Matsirat, Ayer Hangat, Bohor, Ulu Melaka and Kedawang (Figure 2). The population of this research is local residents of Langkawi that consist of 103,075 people (Table 1) (Jabatan Perangkaan Malaysia, 2011). The majority of populations are ethnic Malay $(97 \%)$ with the remainder minority of Chinese and Indians (Marzuki, 2008). Based on the objective of this study, respondents are defined as the 
local residents who have lived on the Island and are still living there during the research period.
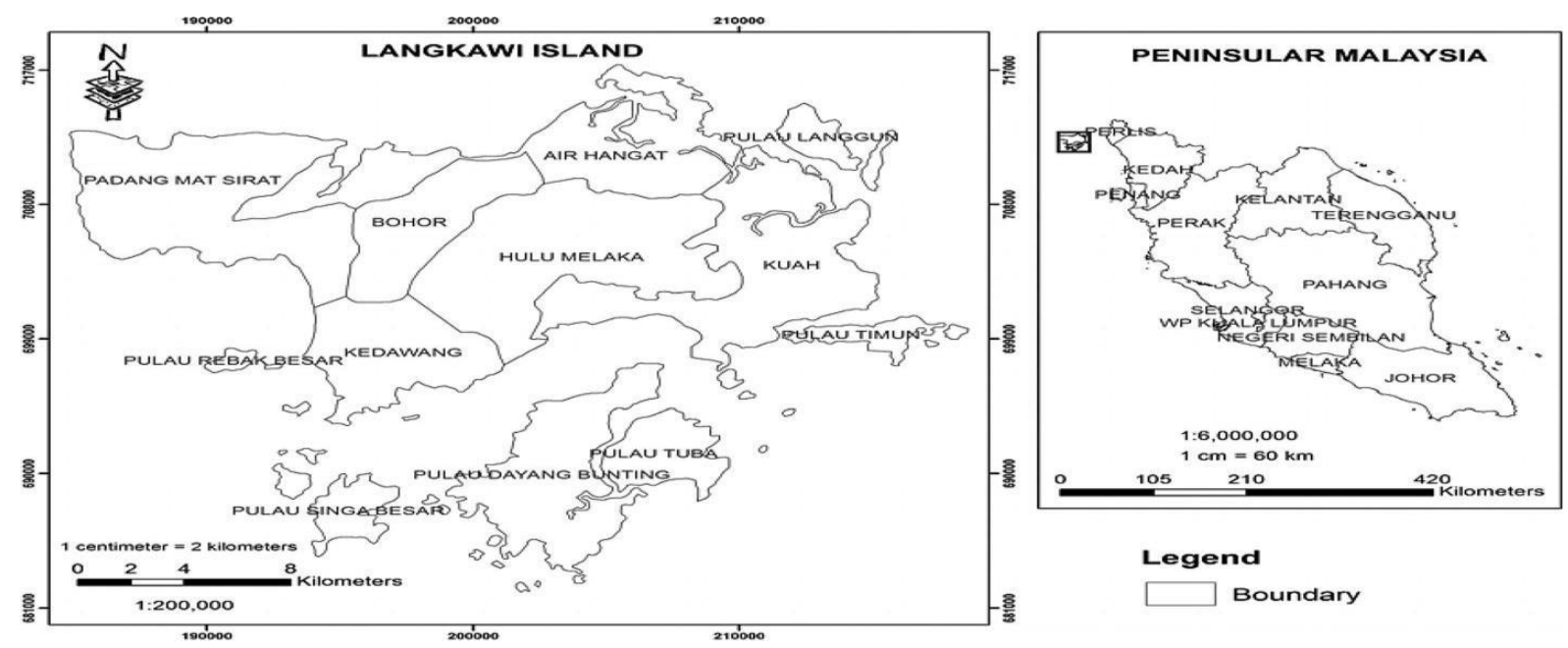

Figure 2. Map of Langkawi Islands and its districts

Source: Irwana Omar, Othman, \& Mohamed, 2014

\subsection{Sample and data collection}

For the specific purpose of this study, the method of stratified random sampling is used. This method has been applied by a number of researchers in tourism field of research (Ribeiro, Valle, and Silva, 2013). The sample population was divided based on the characteristics of local residents and according to the related indicators of study. The two necessary types of residents' characteristics included their residency length and age (Assante et al., 2010). Respondents with elder age may not be more robust towards impacts which tourism create in their community, whereas, younger residents are more tolerant about tourism impacts ( $\mathrm{Gu}$ and Ryan, 2008). Besides, those who have stayed longer in the community may not be more flexible concerning tourism impacts in their community, but, they may be more sensitive towards the tourism development and its subsequent impacts $(\mathrm{Gu}$ and Ryan, 2008).

Moreover, this research follows probability sampling method, in which Krejcie and Morgan table or formula was used to calculate the required sample size. Accordingly, the calculation was done based on the following formula, and the outcome is as below:

$$
\begin{aligned}
& X^{2} * N p(1-p) \\
& d^{2}(N-1)+X^{2} p(1-p)
\end{aligned}
$$

$\mathrm{S}=$ required sample size

$\mathrm{X}^{2}=$ the table value of chi-square for 1 degree of freedom at the desired confidence level (3.841)

$\mathrm{N}=$ the population size

$\mathrm{P}=$ the population proportion (assumed to be 0.5 since this would provide the maximum sample size)

$\mathrm{d}=$ the degree of accuracy expressed as a proportion $(0.05)$ 


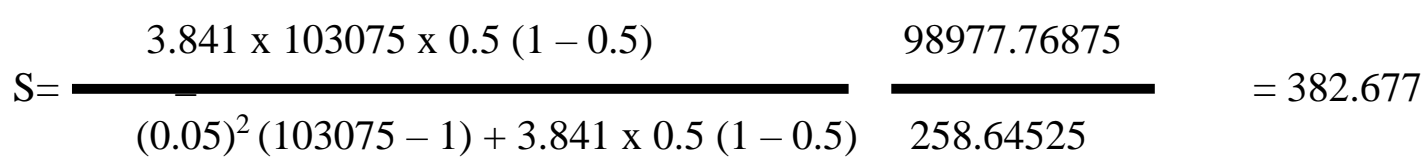

Thus, the total required sample size for the current study was $383(\mathrm{~S}=383)$.

Based on the stratified random sampling, the population was stratified. This technique is used when the population is divided into strata (Taherdoost, 2016). As there were six districts in Langkawi Island; each district was defined as strata. Each strata (district) had a different population size as specified in Table 1, therefore, using proportionate stratification (stratified random sample with proportionate), the following formula was applied to calculate the number of required samples in each district/strata.

Stratified sample formula:

Sample size of the strata $=$ size of entire sample / population size $\mathrm{x}$ layer size

Using stratified random sampling method, a total number of 383 respondents in the six districts of Langkawi Island were selected as a sample of this research. Employing stratified random sample with proportionate allows the survey administrator to collect data from a group of respondents who represent those of a population which may be too large to observe directly. Based on the sampling method of stratified random sample with proportionate, the entire sample size $(S=383)$ counted in this study was divided by the total number of population of Langkawi Island and then multiplied by the number of population size of each strata (district). Table 3.1 shows the sampling calculations for each district accordingly. This enables local residents of every district have an equal chance of being selected as the sample in this study.

Finally, all the required data were collected through July and August in 2016, using self-administered survey questionnaires that were hand-delivered by researcher to 745 local respondents of Langkawi Island at randomly selected addresses. The response rate was $73 \% \%$ according to which 542 usable questionnaires were taken for analysis.

Table 1. District and population

\begin{tabular}{llll}
\hline District & Population & $\begin{array}{l}\text { Minimum sample } \\
\text { size required }\end{array}$ & $\begin{array}{l}\text { Sample size } \\
\text { collected }\end{array}$ \\
\hline Kuah & $383 / 103,075 \times 40,163$ & 149 & 211 \\
\hline Ulu Melaka & $383 / 103,075 \times 16,607$ & 62 & 87 \\
\hline Ayer Hangat & $383 / 103,075 \times 12,654$ & 47 & 67 \\
\hline Padang Matsirat & $383 / 103,075 \times 13,329$ & 49 & 70 \\
\hline Kedawang & $383 / 103,075 \times 12,022$ & 45 & 63 \\
\hline Bohor & $383 / 103,075 \times 8,300$ & 31 & 44 \\
\hline Total & $\mathrm{N}=103,075$ & $\mathrm{~S}=383$ & $\mathrm{~N}=542$ \\
\hline
\end{tabular}

Source: Jabatan Perangkaan Malaysia, 2011

\subsection{Respondents' demographic profile}

Table 2 presents the demography of study sample. The male respondents dominated the samples, representing $64.2 \%$, whereas the females were $35.8 \%$. The misbalance between females and males can be due to using probability sampling method in which every subject 
whether male or female has an equal chance of being included in the sample. The group age was between 18 and 65 years, out of which $29 \%$ were 35 to 44 years old, $24 \%$ of the participants had a group age of 45 to 54 years old, $22.5 \%$ were 25 to 34 , the age group from 18 to 24 years old formed $19.2 \%$ of the sample and finally the 55 years old and above were only $5.4 \%$ of the age group. The other considered demographic factor of this study was length of residency based on number of years; the majority of respondents (54.8\%) stated that they lived in Langkawi Island for 31 years and above. The second major group (13.3\%) of this study was residents, who lived there between 21 and 25 years. $9.6 \%$ of the participants lived in the Island for 16 to 20 years. A small group of the participants $(3.5 \%)$ resided on the Island for 11-15 years. Furthermore, the residents who lived in Langkawi Island for 5 years were $5.9 \%$ and $5.4 \%$ had lived there between $6-10$ years. And finally, $7.6 \%$ of the respondents had lived on the Langkawi Islands between 26-30 years.

Table 2. Respondents' demographic profile $(N=542)$

\begin{tabular}{|c|c|c|}
\hline Variable & Frequency & Percentage \\
\hline \multicolumn{3}{|l|}{ Gender } \\
\hline Male & 348 & $64.2 \%$ \\
\hline Female & 194 & $35.8 \%$ \\
\hline \multicolumn{3}{|l|}{ Age } \\
\hline $18-24$ & 104 & $19.2 \%$ \\
\hline $25-34$ & 122 & $22.5 \%$ \\
\hline $35-44$ & 157 & $29 \%$ \\
\hline $45-54$ & 130 & $24 \%$ \\
\hline $55+$ & 29 & $5.4 \%$ \\
\hline \multicolumn{3}{|l|}{ Length of residency } \\
\hline 5 years & 32 & $5.9 \%$ \\
\hline $6-10$ & 29 & $5.4 \%$ \\
\hline $11-15$ & 19 & $3.5 \%$ \\
\hline $16-20$ & 52 & $9.6 \%$ \\
\hline $21-25$ & 72 & $13.3 \%$ \\
\hline $26-30$ & 41 & $7.6 \%$ \\
\hline $31+$ & 297 & $54.8 \%$ \\
\hline
\end{tabular}

\section{$2.4 \quad$ Measurement scales}

The survey questionnaire for evaluating the study variables was adapted from the review of existing literature, and based on the purpose of this study, slight modifications were further made, and then for more understanding it was translated into Malay language by an authorized language institute in Malaysia. This questionnaire included four sections; in the first section which is resident's demographic profile, the respondents are asked about their age, gender, and length of residency.

The second part of instrument examines respondents' perception of tourism impacts including perceived environmental impacts of tourism, for which the related items were adapted from Ribeiro, Valle, and Silva (2013) and Marzuki (2011), comprising of local infrastructure like roads, civil center and public facilities, beaches and other outdoor places in the island, natural environment and biodiversity, and island landscape, perceived sociocultural impacts of tourism were measured by four items (cultural identity, historical buildings, variety of local cultural activities, and cultural exchange between residents and tourists). These items were adapted from the previous studies conducted by Nunkoo and Gursoy (2012). All the responses for perceived impacts of tourism development were 
examined according to the 5-point Likert scale with 1 (strong negative) and 5 (strong positive).

The third section measures satisfaction with the way of life well-being domain, recreation amenities domain, and satisfaction with overall quality of life. Three items for evaluating way of life included satisfaction with personal life quality, preservation of way of life, and having tourists who respect the locals' way of life, the three items to measure recreation amenities domain consisted of satisfaction with plenty of fairs, festivals, and museums, having live sports to watch in the community and quality recreation opportunities. The responses were evaluated based on five point Likert scale ranging from very satisfied (1) to very dissatisfied (5). And satisfaction with overall quality of life was also measured by three items, including the conditions of my life are excellent so far, I have gotten the important things I want in life, and I am satisfied with my life as a whole. The responses for overall quality of life were measured based on five point Likert scale ranging from strongly agree (1) to strongly disagree (5). All of the items related to non-economic life domains and overall life satisfaction were adapted from the studies conducted by Andereck and Nyaupane (2011) and Woo, Kim, and Uysal (2015), showing a reliable instrument in their studies. Finally, six items were used to assess the local respondents' SSTD which include I participate in tourism-related plans and development to sustain local sociocultural values and traditions, I participate in cultural exchanges between local residents and visitors, I participate in the promotion of environmental education and conservation, I cooperate with tourism planning initiatives to develop local economy and local employment, I support the regulatory environmental standards to reduce the negative impacts of tourism, and I cooperate with tourism planning and development initiatives to promote local products. These items were adapted from the studies done by Lee (2013) with slight modifications which were according to the objectives of this study. Responses on these statements were measured on a five point Likert scale ranging from Strongly Agree (1) to strongly disagree (5).

\section{Results}

The declared results reveal that no significant outlier and missing value was detected after checking the collected data.

For the particular aim of this study, the method of SEM (Structural Equation Modeling) is applied to examine the associations between the observed and latent variables (measurement model) and also the relationships among latent variables so-called structural model. AMOS is employed which is one of the most applicable software to evaluate the required output such as construct reliability, factor loadings, AVE, validity (convergent, discriminant), and validation of the scales used for the measurement of the specific constructs of the model (Hair et al., 2010).

\subsection{Measurement model}

Before the evaluation of structural model of this research, a Confirmatory Factor Analysis (CFA) was conducted. First, the CFA was performed for each of the variables with the associated items. Then, an overall test of CFA was further done, using the six variables comprising of two exogenous variables (perceived environmental impacts of tourism with 4 items, and perceived sociocultural impacts of tourism with 4 items), and four endogenous constructs (satisfaction with way of life with 3 items, satisfaction with recreation amenities with 3 items, overall quality of life with 3 items, and SSTD with 6 items).

The results indicate that the measurement model is fit based on the indices which included chi-square $\left(x^{2}\right)$ value of 560.609 with 215 degrees of freedom $(p=0.000), C M I N / D F$ 
value of 2.607, Goodness-of-fit (GFI) 0.920, Normative Fit Index (NFI) 0.966, Comparative Fit Index (CFI) 0.979, and Root Mean Square Error of Approximation (RMSEA) value of 0.055. Overall, the indices represented a good and acceptable fit of measurement model. The evaluation of convergent validity was done with testing Average Variance Extracted (AVE) and standardized factor loadings. Table 3 displays that the AVE values of all the constructs are above the cutoff value of 0.5 , and the standardized factor loadings were also greater than 0.5 , with all of them above 0.7 , showing an adequate value. The discriminant validity was further tested by comparing the AVE values with the shared squared variances between constructs; the results indicated that all the AVE values were greater than the inter-construct maximum and average shared squared variances (Table 3), showing a statistical difference among the constructs (Hair et al., 2010). Construct reliability was conducted, and the results declared that all the values were higher than the threshold level of 0.7, showing that the items represent the same latent variable (Kline, 2010; Tabachnick, Fidell and Osterlind, 2001). Hence, in the next stage, the structural model was examined.

Table 3. CFA of the measurement model

\begin{tabular}{|c|c|c|c|c|c|c|c|}
\hline Constructs/indicators & $\begin{array}{l}\text { Standardized } \\
\text { factor } \\
\text { loading } \\
\end{array}$ & t-value & $\begin{array}{l}\text { Standard } \\
\text { error }\end{array}$ & $\begin{array}{l}\text { Construct } \\
\text { reliability }\end{array}$ & $\begin{array}{l}\text { Average } \\
\text { variance } \\
\text { extracted }\end{array}$ & MSV & ASV \\
\hline \multicolumn{8}{|l|}{ Perceived environmental } \\
\hline impacts of tourism & & & & 0.967 & 0.879 & 0.155 & 0.070 \\
\hline $\begin{array}{l}\text { 1. Natural environment and } \\
\text { biodiversity }\end{array}$ & 0.966 & - & - & & & & \\
\hline $\begin{array}{l}\text { 2. Local infrastructure such as } \\
\text { roads, civil center and other } \\
\text { public facilities }\end{array}$ & 0.938 & 48.955 & .019 & & & & \\
\hline $\begin{array}{l}\text { 3. Beaches and other outdoor } \\
\text { places }\end{array}$ & 0.914 & 43.481 & .021 & & & & \\
\hline 4. Island landscape & 0.931 & 47.125 & .020 & & & & \\
\hline \multicolumn{8}{|l|}{ Perceived sociocultural } \\
\hline impacts of tourism & & & & 0.908 & 0.712 & 0.158 & 0.091 \\
\hline 1. Cultural identity & 0.806 & - & - & & & & \\
\hline $\begin{array}{l}\text { 2. Variety of local cultural } \\
\text { activities }\end{array}$ & 0.836 & 22.071 & .063 & & & & \\
\hline 3. Historical buildings & 0.902 & 24.298 & .054 & & & & \\
\hline $\begin{array}{l}\text { 4. Cultural exchange between } \\
\text { residents and tourists }\end{array}$ & 0.827 & 21.763 & .060 & & & & \\
\hline Way of life domain & & & & 0.908 & 0.768 & 0.065 & 0.033 \\
\hline $\begin{array}{l}\text { 1. Satisfaction with personal } \\
\text { life quality }\end{array}$ & 0.869 & - & - & & & & \\
\hline 2. Preservation of way of life & 0.893 & 26.582 & .038 & & & & \\
\hline $\begin{array}{l}\text { 3. Having tourists who respect } \\
\text { my way of life }\end{array}$ & 0.866 & 25.667 & .039 & & & & \\
\hline \multicolumn{8}{|l|}{ Recreation amenities life } \\
\hline domain & & & & 0.890 & 0.730 & 0.158 & 0.070 \\
\hline $\begin{array}{l}\text { 1. Satisfaction with plenty of } \\
\text { fairs, festivals, and museums }\end{array}$ & 0.831 & - & - & & & & \\
\hline $\begin{array}{l}\text { 2. Having live sports to watch } \\
\text { in my community }\end{array}$ & 0.849 & 22.661 & .038 & & & & \\
\hline $\begin{array}{l}\text { 3. Quality recreation } \\
\text { opportunities }\end{array}$ & 0.883 & 23.438 & .044 & & & & \\
\hline Overall quality of life & & & & 0.945 & 0.851 & 0.047 & 0.035 \\
\hline $\begin{array}{l}\text { 1. The conditions of my life are } \\
\text { excellent So far }\end{array}$ & 0.892 & - & - & & & & \\
\hline $\begin{array}{l}\text { 2. I have gotten the important } \\
\text { things I want in life }\end{array}$ & 0.927 & 33.978 & .030 & & & & \\
\hline
\end{tabular}


3. I am satisfied with my life as a whole

Support for sustainable

\section{tourism development}

1. I participate in tourismrelated plans and development to sustain local sociocultural

values and traditions

2. I participate in cultural

exchanges between local residents and visitors

3. I participate in the promotion of environmental education and conservation

4. I cooperate with tourism planning initiatives to develop local economy and local employment

5. I support the regulatory environmental standards to reduce the negative impacts of tourism

6. I cooperate with tourism planning and development initiatives to promote local products
$0.947 \quad 35.429 \quad .030$

$\begin{array}{llll}0.993 & 0.960 & 0.060 & 0.047\end{array}$

0.989

$0.982 \quad 94.482 \quad .010$

$0.977 \quad 88.044 \quad .011$

$0.986 \quad 102.578 \quad .010$

$0.979 \quad 89.738 \quad .011$

$0.965 \quad 74.842 \quad .013$

\subsection{Structural model}

This research applies structural equation modelling (SEM) approach and includes six variables and seven paths in its structural model. The relationship among the six constructs (perceived sociocultural impacts, perceived environmental, satisfaction with recreation amenities, satisfaction with way of life, overall quality of life satisfaction, and SSTD) was tested, using maximum likelihood (ML). The outcomes of the structural model revealed a chisquare $\left(\mathrm{x}^{2}\right)$ value of 613.007 with 222 degrees of freedom $(\mathrm{p}=0.000)$, CMIN/DF value of 2.761, GFI 0.913, NFI 0.963, CFI 0.976, and the RMSEA 0.057. Hence, all the indices had the accepted level of value.

Table 4 shows the results of hypotheses test. Out of the seven proposed hypotheses, six were accepted and only hypothesis five (H5) was rejected. The first hypothesis showed that residents' satisfaction with overall quality of life had a significant impact on the residents' SSTD (H1). Likewise, the recreation amenities and way of life domains as the two important life domains significantly influenced overall quality of life satisfaction ( $\mathrm{H} 2$ and H3). The fourth hypothesis further showed that perceived environmental impacts of tourism had a significant influence on the recreation amenities domain (H4). Finally, perceived sociocultural impacts of tourism significantly affected both the recreation amenities and way of life domains (H6 and H7). 
Table 4. Results of structural model

\begin{tabular}{|c|c|c|c|c|c|c|c|}
\hline Hypotheses & \multicolumn{3}{|c|}{ Hypothesized paths } & Standardized & S.E. & $\mathrm{t}$-value & $\mathrm{P}$ \\
\hline H1 & $\begin{array}{l}\text { Overall quality of } \\
\text { life }\end{array}$ & $\rightarrow$ & $\begin{array}{l}\text { Support for } \\
\text { sustainable } \\
\text { tourism } \\
\text { development }\end{array}$ & 0.219 & 0.051 & 5.022 & $* * *$ \\
\hline $\mathrm{H} 2$ & $\begin{array}{l}\text { Recreation } \\
\text { amenities domain }\end{array}$ & $\rightarrow$ & $\begin{array}{l}\text { Overall quality } \\
\text { of life }\end{array}$ & 0.173 & 0.049 & 3.748 & $* * *$ \\
\hline $\mathrm{H} 3$ & $\begin{array}{l}\text { Way of life } \\
\text { domain }\end{array}$ & $\rightarrow$ & $\begin{array}{l}\text { Overall quality } \\
\text { of life }\end{array}$ & 0.153 & 0.042 & 3.340 & $* * *$ \\
\hline $\mathrm{H} 4$ & $\begin{array}{l}\text { Perceived } \\
\text { environmental } \\
\text { impacts of tourism }\end{array}$ & $\rightarrow$ & $\begin{array}{l}\text { Recreation } \\
\text { amenities } \\
\text { domain }\end{array}$ & 0.163 & 0.040 & 3.475 & $* * *$ \\
\hline H5 & $\begin{array}{l}\text { Perceived } \\
\text { environmental } \\
\text { impacts of tourism }\end{array}$ & $\rightarrow$ & $\begin{array}{l}\text { Way of life } \\
\text { domain }\end{array}$ & 0.068 & 0.048 & 1.429 & 0.153 \\
\hline H6 & $\begin{array}{l}\text { Perceived } \\
\text { sociocultural } \\
\text { impacts of tourism }\end{array}$ & $\rightarrow$ & $\begin{array}{l}\text { Recreation } \\
\text { amenities } \\
\text { domain }\end{array}$ & 0.335 & 0.042 & 6.713 & $* * *$ \\
\hline $\mathrm{H} 7$ & $\begin{array}{l}\text { Perceived } \\
\text { sociocultural } \\
\text { impacts of tourism }\end{array}$ & $\rightarrow$ & $\begin{array}{l}\text { Way of life } \\
\text { domain }\end{array}$ & 0.228 & 0.049 & 4.474 & $* * *$ \\
\hline
\end{tabular}

\subsection{Discussion of results}

As presented in Figure 3, the results gained from the SEM analysis indicate that there is a significant relationship between perceived environmental impacts of tourism and the residents' satisfaction with the recreation amenities which is considered as one of the life domains $(\mathrm{H} 4, \mathrm{~B}=0.163, \mathrm{P}<0.001)$. It implies that residents, who perceive the environmental impacts as beneficial, find that their life is positively affected and have more recreation opportunities including fairs, festivals, and live sports due to tourism development in their community. However, this relation was insignificant on the domain of residents' way of life which was taken as the other non-economic life domain, and accordingly this hypothesis (H5, $\mathrm{B}=0.068, \mathrm{P}=0.153$ ) was rejected. The findings also showed that perceived sociocultural impacts of tourism had a positive and significant influence on both recreation amenities and way of life domains $(\mathrm{H} 6, \mathrm{~B}=0.335, \mathrm{P}<0.001$ and $\mathrm{H} 7, \mathrm{~B}=0.228, \mathrm{P}<0.001)$. The residents perceive that tourists respect their traditional lifestyle, and that their local lifestyle is preserved through local cultural identity or variety of cultural activities due to tourism development. However, this relationship was stronger on the residents' satisfaction with recreation amenities $(\mathrm{B}=0.335, \mathrm{P}<0.001)$; it may depend on the level of people's appreciation and tendency which is more towards entertainment and recreation amenities owing to positive sociocultural activities of tourism development in their community in comparison to the way of life $(\mathrm{B}=0.228, \mathrm{P}<0.001)$.

Moreover, this study also proved that the residents' satisfaction with recreation amenities and way of life domains had a positive influence on their satisfaction with overall quality of life $(\mathrm{H} 2, \mathrm{~B}=0.173, \mathrm{P}<0.001$ and $\mathrm{H} 3, \mathrm{~B}=0.153, \mathrm{P}=<0.001)$, showing that positive changes in subdomains and life domains positively spill over to the overall quality of life satisfaction. This finding is in consistent with the theory of bottom-up spilloverand also with the previous studies (Woo, Kim, \& Uysal (2015), implying that residents' satisfaction with 
different life subdomains and life domains substantially affect the overall quality of life (Uysal, Perdue, \& Sirgy, 2012; Woo, Kim, \& Uysal, 2015).

Lastly, the results indicated that overall quality of life had a significant and positive relationship with the SSTD $(\mathrm{H} 1, \mathrm{~B}=0.219, \mathrm{P}<0.001)$. According to the literature reviewed, previous studies mostly investigated the relationship between tourism impacts and quality of life satisfaction as the ultimate dependent construct, while quality of life satisfaction has hardly ever been tested on support for tourism and very few empirically tested results have been declared (Croes, 2012; Uysal, Perdue, \& Sirgy, 2012; Woo, Kim, \& Uysal, 2015). More critically, no study was found to include merely non-economic factors of tourism impacts and non-economic life domains in a comprehensive and integrated theoretical model to test on the residents' SSTD in the Island context. Hence, this study filled this research gap. Accordingly, the findings revealed that tourism in terms of non-economic impacts influenced noneconomic life domains which in turn affected overall quality of life and ultimately residents' satisfaction with overall quality of life had a positive and significant relation with their SSTD. As a result, the more satisfied the residents feel about their quality of life, the more they support sustainable tourism development. Therefore, this outcome confirms the validity of social exchange theory as well.

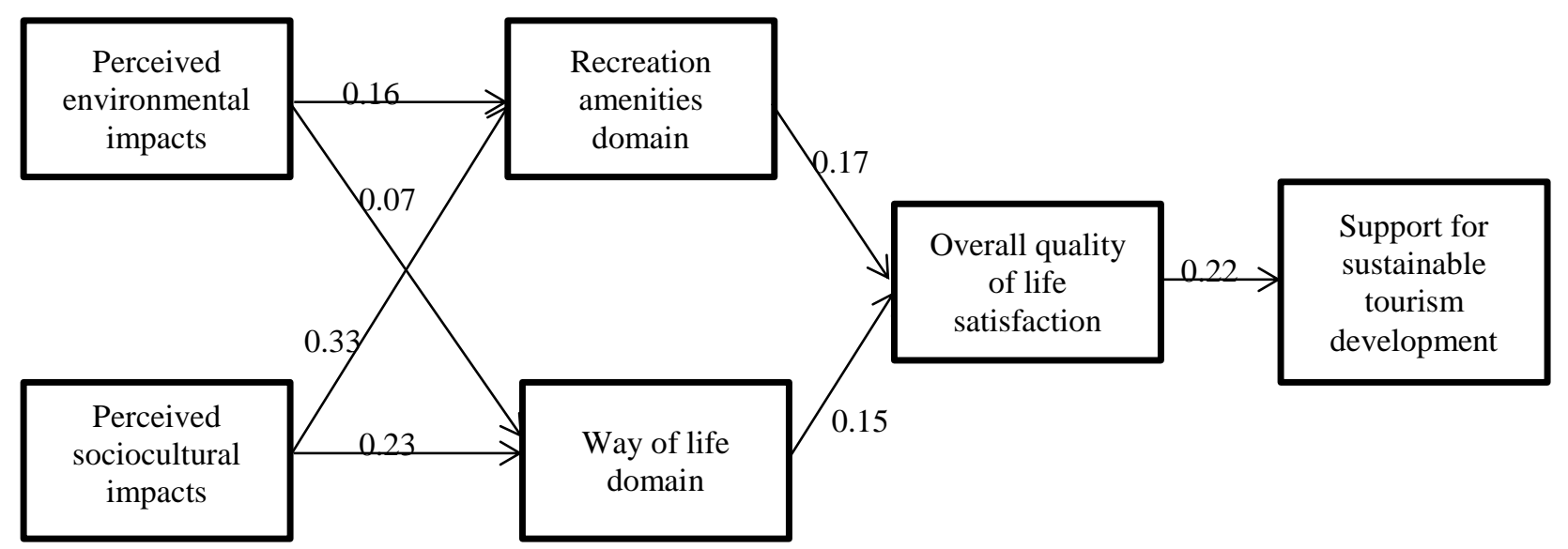

Figure 3. The conceptual model of residents' support for sustainable tourism development

\section{Conclusion, Limitations and recommendation for future study}

This study uses non-economic factors of tourism impact dimensions and life domains to develop a conceptual framework of residents' SSTD in Langkawi Island. Using the noneconomic variables in the model based on SET and Bottom-up spillover theory, the findings of this research confirm the conceptual model which was empirically tested among the local community of Langkawi Island, indicating that non-economic factors also have influence on the residents' perception towards SSTD. The proposed model of this research additionally enhances the knowledge regarding local residents' perceptions of a community by validating how perceived sociocultural and environmental impacts of tourism as two non-economic factors affect satisfaction with recreation amenities and way of life domains which influence the overall quality of life, and finally result in residents' SSTD. Therefore, the importance of this study is the development of a theoretical model by applying merely non-economic factors as the new analysts of residents' SSTD. In practice, this study also helps the local consultants, officials and planners have a clear point of view regarding what to take into consideration in regard to developing tourism industry in the island context which is limited and sensitive in terms of geographic situation and also what to reflect while attracting local residents' participation in developing sustainable tourism in their community. 
Apart from the theoretical and empirical implications, this study has few limitations. First, the current study used only two non-economic life domains which may limit its findings. Future studies should integrate other non-economic life domains such as satisfaction with community pride, and emotional well-being to improve the predictive power of model. Moreover, since other destinations and Islands may have different levels of tourism development, geographic, demographic, cultural, and behavioral conditions, future studies may find different results of testing non-economic factors in those destinations which may not be consistent with the findings of this study. Therefore, to have a better validity of the current proposed theoretical framework with the application of non-economic variables, this study recommends that future studies examine this model in the other destinations where tourism is the main industry for the local community.

\section{References}

Andereck, K. L. \& Nyaupane, G. P. (2011). Exploring the nature of tourism and quality of life perceptions among residents. Journal of Travel Research.

Andereck, K. L., Valentine, K. M., Knopf, R. C. \& Vogt, C. A. (2005). Residents' perceptions of community tourism impacts. Annals of tourism research, 32, 1056-1076.

Andereck, K. L., Valentine, K. M., Vogt, C. A. \& Knopf, R. C. (2007). A cross-cultural analysis of tourism and quality of life perceptions. Journal of Sustainable Tourism, 15, 483-502.

Andereck, K. L. \& Vogt, C. A. (2000). The relationship between residents' attitudes toward tourism and tourism development options. Journal of Travel research, 39, 27-36.

Androniceanu, A. (2017). Hospital management based on the relationship between doctors and patients. Administratie si Management Public, 29, 41-53.

Ap, J. (1992). Residents' perceptions on tourism impacts. Annals of tourism Research, 19, 665-690.

Aref, F. (2011). The effects of tourism on quality of life: A Case Study of Shiraz, Iran. Life Science Journal, 8, 26-30.

Assante, L. M., Wen, H. I., Lottig, K. \& Hotels, S. (2010). An empirical assessment of residents' attitudes for sustainable tourism development: a case study of $O$ 'ahu, Hawai'i. Journal of Sustainability and Green Business, 2, 27.

Butler, R.W. (1999). Sustainable tourism: A state of the art review. Tourism Geographies, 1(1), 7-25.

Chen, C.-F. \& Chen, P.-C. (2010). Resident attitudes toward heritage tourism development. Tourism Geographies, 12, 525-545.

Croes, R. (2012). Assessing tourism development from Sen's capability approach. Journal of Travel Research, 51, 542-554.

Fallon, L. D., \& Kriwoken, L. K. (2003). Community involvement in tourism infrastructure: the case of the Strahan Visitor Centre, Tasmania. Tourism Management, 24, 289e308.

Gu, H. \& Ryan, C. (2008). Place attachment, identity and community impacts of tourism-the case of a Beijing hutong. Tourism management, 29, 637-647.

Gursoy, D., Chi, C. G. \& Dyer, P. (2009). An examination of locals' attitudes. Annals of Tourism Research, 36, 723-726.

Gursoy, D., Chi, C. G. \& Dyer, P. (2010). Locals' attitudes toward mass and alternative tourism: The case of Sunshine Coast, Australia. Journal of Travel Research.

Gursoy, D. \& Rutherford, D. G. (2004). Host attitudes toward tourism: An improved structural model. Annals of Tourism Research, 31, 495-516.

Hair, J., Black, W., Babin, B., Anderson, R. \& Tatham, R. (2010). Multivariate Data Analysis New Jersey: Pearson Prentice Hall. 
Hanafiah, M. H., Jamaluddin, M. R. \& Zulkifly, M. I. (2013). Local Community Attitude and Support towards Tourism Development in Tioman Island, Malaysia. Procedia-Social and Behavioral Sciences, 105, 792-800.

Homans, G. C. (1961). Social behavior: Its elementary forms. Wiley Publisher, 63, 6.

Huong, P. M. \& Lee, J.-H. (2017). Finding important factors affecting local residents' support for tourism development in $\mathrm{Ba}$ Be National Park, Vietnam. Forest Science and Technology, 13, 126-132.

Irwana Omar, S., Ghapar Othman, A. \& Mohamed, B. (2014). The tourism life cycle: an overview of Langkawi Island, Malaysia. International Journal of Culture, Tourism and Hospitality Research, 8, 272-289.

Istvan O. Egresi \& Fatih Kara (2016). Residents' attitudes to tourists visiting their mosques: a case study from Istanbul, Turkey, Journal of Tourism and Cultural Change, 1747-7654.

Jeon, M. M., Kang, M. M. \& Desmarais, E. (2014). Residents' perceived quality of life in a cultural-heritage tourism destination. Applied Research in Quality of Life, 1-19.

Jurowski, C., Uysal, M. \& Williams, D. R. (1997). A theoretical analysis of host community resident reactions to tourism. Journal of travel research, 36, 3-11.

Kayat, K. (2002). Power, social exchanges and tourism in Langkawi: Rethinking resident perceptions. International Journal of Tourism Research, 4 (3), 171-191.

Kibicho, W. (2004). Community tourism: A lesson from Kenya's coastal region. Journal of Vacation Marketing, 10, 33-42.

Kim, K. (2002). The effects of tourism impacts upon quality of life of residents in the community. Virginia Polytechnic Institute and State University.

Kim, K., Uysal, M. \& Sirgy, M. J. (2013). How does tourism in a community impact the quality of life of community residents? Tourism Management, 36, 527-540.

Kline, R. B. (2010). Principles and practice of structural equation modeling, Guilford press.

Ko, D.-W. \& Stewart, W. P. (2002). A structural equation model of residents' attitudes for tourism development. Tourism management, 23, 521-530.

Kot, S. (2018). Sustainable supply chain management in small and medium enterprises. Sustainability, 10 (4), art. no. 1143

Lee, T. H. (2013). Influence analysis of community resident support for sustainable tourism development. Tourism Management, 34, 37-46.

Luekveerawattana, R. (2018). Key factors affecting of tourists' decisions to stay at environmental friendly hotels. Polish Journal of Management Studies, 17 (2), 148-157.

Marzuki, A. (2008). Decision making and community participation: A case study of the tourism industry in Langkawi. Turizam: znanstveno-stručničasopis, 56, 227-241.

Marzuki, A. (2011). Resident attitudes towards impacts from tourism development in Langkawi Islands, Malaysia. World Applied Sciences Journal, 12, 25-34.

McGehee, N. G. \& Andereck, K. L. (2004). Factors predicting rural residents' support of tourism. Journal of Travel Research, 43, 131-140.

Mihalic, T., Segota, T., KnezevicCvelbar, L. \& Kuscer, K. (2016). The influence of the political environment and destination governance on sustainable tourism development: a study of Bled, Slovenia. Journal of Sustainable Tourism, 24, 1489-1505.

Mowforth, and M. Munt. (1998). Tourism and sustainability: new tourism in the Third World. London, Routledge.

Nawijn, J. \& Mitas, O. (2012). Resident attitudes to tourism and their effect on subjective well-being: The case of Palma de Mallorca. Journal of Travel Research, 51, 531-541.

Neal, J. D., Sirgy, M. J. \& Uysal, M. (1999). The role of satisfaction with leisure travel/tourism services and experience in satisfaction with leisure life and overall life. Journal of Business Research, 44, 153-163. 
Northcote, J. \& Macbeth, J. (2005). Limitations of Resident Perception Surveys for Understanding Tourism Social Impacts The Need for Triangulation. Tourism Recreation Research, 30, 43-54.

Nicholas, L. N., Thapa, B. \& Ko, Y. J. (2009). Residents' perspective of a world heritage site: The pitons management area, St. Lucia. Annals of Tourism Research, 36, 390-412.

Niemczyk, A. (2015), Family Decisions on the Tourist Market, Economics and Sociology, Vol. 8, No 3, pp. 272-283. DOI: 10.14254/2071-789X.2015/8-3/19

Nunkoo, R. \& Gursoy, D. (2012). Residents' support for tourism: An identity perspective. Annals of Tourism Research, 39, 243-268.

Nunkoo, R. \& Ramkissoon, H. (2011a). Developing a community support model for tourism. Annals of Tourism Research, 38, 964-988.

Nunkoo, R. \& Ramkissoon, H. (2011b). Residents' satisfaction with community attributes and support for tourism. Journal of Hospitality \& Tourism Research, 35, 171-190.

Nunkoo, R. \& Ramkissoon, H. (2012). Power, trust, social exchange and community support. Annals of Tourism Research, 39, 997-1023.

Nunkoo, R., \& So, K. K. F. (2016). Residents' support for tourism: Testing alternative structural models. Journal of Travel Research, 55, 847-861.

Pejabat Daerah Langkawi (2011). Penduduk. Retrieved from http://pdlangkawi.blogspot.com/2011/03/penduduk.html.

Perdue, R. R., Long, P. T. and Allen, L. (1990). Resident support for tourism development. Annals of Tourism Research, 17, 586-599.

Perdue, R. R., Long, P. T. and Kang, Y. S. (1999). Boomtown tourism and resident quality of life: The marketing of gaming to host community residents. Journal of Business Research, 44, 165-177.

Pjerotic, L. (2017). Stakeholder cooperation in implementation of the sustainable development concept: Montenegrin tourist destinations. Journal of International Studies, 10(2), 148-157. doi:10.14254/2071-8330.2017/10-2/11

Puczko, L. \& Ratz, T. (2000). Tourist and resident perceptions of the physical impacts of tourism at Lake Balaton, Hungary: Issues for sustainable tourism management. Journal of Sustainable Tourism, 8, 458-478.

Ribeiro, M. A., Valle, P. O. d. \& Silva, J. A. (2013). Residents' attitudes towards tourism development in Cape Verde Islands. Tourism Geographies, 15, 654-679.

Ritchie, B. W., \& Inkari, M. (2006). Host community attitudes toward tourism and cultural tourism development: The case of the Lewes District, Southern England. International Journal of Tourism Research, 8(1), 27-44.

Shengrong Chen, Suosheng Wang \& Honggang Xu (2017). Influence of Place Identity on Residents' Attitudes to Dark Tourism, Journal of China Tourism Research, 13, 338356.

Shuaibu, M., \& Oladayo, P. (2016). Determinants of human capital development in Africa: a panel data analysis. Oeconomia Copernicana, 7(4), 523-549. https://doi.org/10.12775/OeC.2016.030.

Jun, SH., Pongsata, P., \& Noh J. (2016). An Examination of Residents' Support for Tourism Development in Thailand". Tourism Travel and Research Association: Advancing Tourism Research Globally, 15.

Sirgy, M. J. \& Lee, D.-J. (2006). Macro measures of consumer well-being (CWB): a critical analysis and a research agenda. Journal of Macromarketing, 26, 27-44.

Strielkowski, W. (2018). Heritage, screen and literary tourism. Tourism Management, 69, 537-537. doi: 10.1016/j.tourman.2018.07.004

Strielkowski, W. (2017). Promoting Tourism Destination through Film-Induced Tourism: The Case of Japan. Market-Trziste, 29(2), 193-203. doi:10.22598/mt/2017.29.2.193 
Streimikiene, D., \& Bilan, Y. (2015). Review of rural tourism development theories. Transformations in Business \& Economics, 14(2), 21-34.

Strzelecka, M., Boley, B. B. \& Strzelecka, C. (2017). Empowerment and resident support for tourism in rural Central and Eastern Europe (CEE): the case of Pomerania, Poland. Journal of Sustainable Tourism, 25, 554-572.

Stylidis, D. \& Terzidou, M. (2014). Tourism and the economic crisis in Kavala, Greece. Annals of Tourism Research, 44, 210-226.

Stylidis, D., Biran, A., Sit, J. \& Szivas, E. M. (2014). Residents' support for tourism development: The role of residents' place image and perceived tourism impacts. Tourism Management, 45, 260-274.

Suntikul, W., Pratt, S., I Kuan, W., Wong, C. I., Chan, C. C., Choi, W. L. \& Chong, O. F. (2016). Impacts of tourism on the quality of life of local residents in Hue, Vietnam. Anatolia, 27, 405-420.

Tabachnick, B. G., Fidell, L. S. \& Osterlind, S. J. (2001). Using multivariate statistics.

Taherdoost, H. (2016). Sampling methods in research methodology; How to choose a sampling technique for research. International Journal of Academic Research in Management, 5, 18-27.

Tovar, C., \& Lockwood, M. (2008). Social impacts of tourism: An Australian regional case study. International Journal of Tourism Research, 10(4), 365-378.

United Nations Environment Programme (UNEP) and World Tourism Organisation (WTO). (2005). Making tourism more sustainable: A guide for policymakers.

Uysal, M., Perdue, R. \& Sirgy, M. J. (2012). Handbook of tourism and quality-of-life research: Enhancing the lives of tourists and residents of host communities. Dordrecht, the Netherlands: Springer.

Vargas-Sanchez, A., de los Angeles Plaza-Mejia, M. \& Porras-Bueno, N. (2009). Understanding residents' attitudes toward the development of industrial tourism in a former mining community. Journal of Travel Research, 47, 373-387.

Victoria M. Waligo, \& J. C., Rebecca Hawkins (2013). Implementing sustainable tourism: A multi-stakeholder involvement management framework. Tourism management, 36, 342353.

Wang, Y. A. \& Pfister, R. E. (2008). Residents' attitudes toward tourism and perceived personal benefits in a rural community. Journal of Travel Research, 47, 84-93.

Woo, E., Kim, H. \& Uysal, M. (2014). A measure of quality of life in elderly tourists. Applied Research in Quality of Life, 1-18.

Woo, E., Kim, H. \& Uysal, M. (2015). Life satisfaction and support for tourism development. Annals of Tourism Research, 50, 84-97.

Yu, C.-P. S., Chancellor, H. C. \& Cole, S. T. (2011). Examining the Effects of Tourism Impacts on Resident Quality of Life. International Journal of Tourism Sciences, 11, 161-186.

Zhang, Y., Cole, S. T. \& Chancellor, C. H. (2013). Residents' preferences for involvement in tourism development and influences from individual profiles. Tourism Planning \& Development, 10, 267-284. 